\title{
Analysing stakeholders' perceptions of wolf, lynx and fox in a Dutch riverine area
}

\author{
B. F. van Heel ${ }^{1,2}$ - A. M. Boerboom ${ }^{1,2}$ J. M. Fliervoet $^{1}$ • \\ H. J. R. Lenders ${ }^{2} \cdot$ R. J. G. van den Born ${ }^{1}$
}

Received: 11 July 2016/Revised: 15 February 2017/ Accepted: 27 February 2017 /

Published online: 9 March 2017

(C) The Author(s) 2017. This article is published with open access at Springerlink.com

\begin{abstract}
In the last decades, populations of large carnivores have been making a spectacular return, especially in the USA and Western Europe. These population recoveries result partially from protective legislation and reintroduction programs, but possibly also from land use changes and from large carnivores adapting to human environments. Although public support for large carnivore protection seems to be growing, some stakeholders still have a negative perception of large carnivores because of their alleged negative impacts on livestock and humans. Perceptions of large carnivores are partly determined by underlying visions of nature which differ between stakeholder groups. We therefore examined the relationship between different stakeholder groups' perceptions of nature and the presence of the fox (Vulpes vulpes), and the possible establishment of the wolf (Canis lupus) and lynx (Lynx lynx) in a Dutch riverine landscape. Stakeholder groups comprised the general public, farmers, scientists and nature conservationists. Although perceptions of large carnivores differed significantly across the stakeholder groups, public support for large carnivores was generally higher than expected. Farmers show the most negative perception, especially regarding the wolf and lynx. This is related to their vision
\end{abstract}

Communicated by Dirk Sven Schmeller.

B. F. van Heel and A. M. Boerboom have equally contributed on this work.

This article belongs to the Topical Collection: Biodiversity appreciation and engagement.

Electronic supplementary material The online version of this article (doi:10.1007/s10531-017-1329-5) contains supplementary material, which is available to authorized users.

R. J. G. van den Born

r.vandenborn@fnwi.ru.nl

1 Institute for Science, Innovation and Society, Faculty of Science, Radboud University Nijmegen, P.O. Box 9010, 6500 GL Nijmegen, The Netherlands

2 Department of Environmental Science, Institute for Water and Wetland Research, Faculty of Science, Radboud University Nijmegen, P.O. Box 9010, 6500 GL Nijmegen, The Netherlands 
of nature, which is more strongly aligned with mastery over nature compared to other stakeholder groups. Scientists, prominent adherers of stewardship of nature, appear to have the most positive perception of large carnivores. Despite these differences in visions of nature, respondents generally adhere to the stewardship of nature relationship. This could be a good starting point to find common ground when disputes arise over large carnivores.

Keywords Carnivores · Attitudes · The Netherlands · Wildlife management · Human-nature relationship · Survey

\section{Introduction}

Conservation management of large carnivores, such as tigers in Bhutan and leopards in India, is a worldwide challenge because it involves species that are often rare and controversial (Bhattacharjee and Parthasarathy 2013; Frank et al. 2015; Sangay and Vernes 2008). In Western Europe, large carnivores, especially the wolf (Canis lupus) and lynx (Lynx lynx), are currently making a spectacular return (Enserink and Vogel 2006), indisputably resulting from successful legislative protection and reintroduction programs (Chapron et al. 2014), but possibly also from land-use changes and adaptation of populations to human pressures. The largest populations of lynx are currently found in Northern and Eastern Europe with a total number of approximately 9000-10,000 individuals (Kaczensky et al. 2012). The number of wolves in Europe is estimated to be over 10,000 individuals. Wolves are nowadays found in most countries in Europe (Mech and Boitani 2010). Galaverni and colleagues (2016) argue that these qualitative evaluations likely underestimate the actual numbers. In some parts of Europe, wolf populations quickly increased (Czarnomska et al. 2013; Nowak and Mysłajek 2016); for example, eastern Poland saw an increase of 38\% a year (Nowak and Mysłajek 2016). Increases in wolf populations are also observed in Scandinavia, the Alps and the Baltic (Kaczensky et al. 2012).

An important additional factor in the successful return of wolves and lynxes in humandominated landscapes may be an increasingly supportive public opinion towards large carnivores. Research indicates that growing public support for large carnivores is driven by, amongst other factors, increased affluence, education, knowledge and urbanization (Chapron et al. 2014; Glikman et al. 2012; Manfredo et al. 2003). Money may not necessarily influence perception (Marino et al. 2016). A more positive perception of large carnivores is found amongst people with a higher education and urban area dwellers (Kleiven et al. 2004; Røskaft et al. 2003). Perception of large carnivores is also influenced by people's relationship with nature, and by experienced and expected risk of, or familiarity with, carnivores (Røskaft et al. 2003, 2007; Vitters $\varnothing$ et al. 1999).

Despite growing public support, the return of large carnivores to areas with high human densities raises the debate of whether there is still room for them and whether human communities should be separated from populations of large carnivores (Enserink and Vogel 2006; Linnell et al. 2001). This debate stresses the importance of understanding social, political and cultural dimensions of conservation management of large carnivores (Bruskotter and Shelby 2010). Large carnivores are a controversial group of species to manage because of a "deeply rooted hostility to these species in human history and culture" (Chapron et al. 2014). This hostility is a result of a negatively perceived impact of 
large carnivores on human societies where a conflict arises between the interests of humans and carnivores (Thorn et al. 2013). An example of a human-carnivore conflict is the increased threat to livestock due to reintroduced wolves in Yellowstone National Park. This conflict led to the removal of 250 wolves in 2001 (Bruskotter and Shelby 2010). The human-carnivore conflict can be characterized by perceived predation losses and perceived culpability, persecution and tolerance of carnivores (Thorn et al. 2013). Human-carnivore interactions may lead to conflicts between different stakeholder groups because of different perspectives on large carnivore management (Marshall et al. 2007; Treves and Karanth 2003). Existence of large carnivores alongside modern, high-density human societies requires effective regulation to mediate in the human-carnivore conflict (Bruskotter and Shelby 2010; Chapron et al. 2014; Linnell et al. 2001). In sum, carnivore management is dependent on the socio-political landscape as much as on the biological landscape (Treves and Karanth 2003).

In March 2015, a wild wolf visited the Netherlands for the first time in over a century (Pijpker 2015). This intensified the public debate on conservation management of large carnivores in the Netherlands (Drenthen 2014, 2015). However, studies on public perceptions of large carnivores gained little attention in the Netherlands compared to Scandinavian countries (Glikman and Frank 2011). Moreover, in previous research underlying visions of nature-representing the way in which people perceive nature, the different values people adhere to nature and the way in which people reflect on their ideal relationship with nature (Van den Born 2007)—have been largely neglected. Therefore, the aim of this paper is to investigate perceptions regarding large carnivores among Dutch stakeholders. Because one's visions of nature can influence the perception of large carnivores, we also examine the relationship between the stakeholders' preferred humannature relationship and their perception of large carnivores. Because of possible conflicting interests, values and perceptions regarding large carnivores and their impact on personal and professional livelihood, our focus is on farmers, scientists, nature conservationists and the general public as stakeholder groups to be investigated.

This research is geographically confined to Lingestreek, a largely agricultural area at the heart of the Dutch River District, located near the German border, where wolves already occasionally appear, and between four large nature reserves which function as potential habitats for large carnivores: the Veluwe, Utrechtse Heuvelrug, Gelderse Poort and Reichswald (Fig. 1). Predatory visits by large carnivores into Lingestreek can certainly not be ruled out, once individuals or populations have settled in these adjacent nature reserves. Potential prey for large carnivores is available in the form of semi-wild cattle and horses, as well as naturally occurring wildlife in nature rehabilitation areas in the floodplains along the rivers Waal and Rhine which border Lingestreek. However, since the study area itself has mainly an agricultural function, livestock is potential prey as well, and conflicts between humans and carnivores cannot be ruled out. This setting makes Lingestreek an ideal area for a stakeholder perception study towards large carnivores.

As focal species we selected the fox (Vulpes vulpes), the wolf and the lynx. The fox was selected as a reference species since it already inhabits Lingestreek and stakeholders may already have experienced the species in a positive or negative manner. Wolves and lynx do not live in the study area but may (re)colonize the area in the near future. The general public in Europe has little basic knowledge of the wolf's biology and even less of that of the lynx (Bath et al. 2008; Lescureux et al. 2011). In contrast to the wolf, which still features (usually negatively) in fairy tales and stories, many people are not even aware of the existence of the lynx as a species indigenous to Europe. Perceptions of wolf and lynx may therefore differ due to different levels of bias towards both species. 


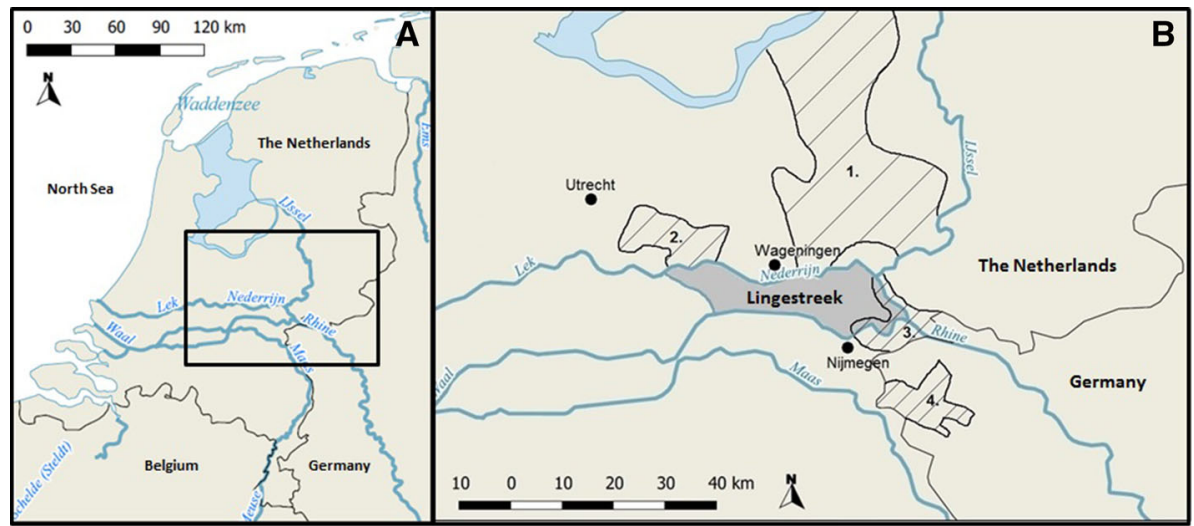

Fig. 1 a Location of study area in the Netherlands and b the location of Lingestreek (grey area). The figures are based on the geographic coordinates of Amersfoort. The numbered areas indicate the large nature reserves, which function as potential habitats for large carnivores: (1) the Veluwe, (2) Utrechtse Heuvelrug (3) Gelderse Poort and (4) Reichswald (in Germany)

We translated our research aim into the following research question: 'What are the perceptions of farmers, scientists, nature conservationists and the general public regarding the presence of the fox and the possible establishment of the wolf and lynx in the Lingestreek area?' This research question is explored by using a quantitative approach based on a survey. The survey included questions regarding the human-nature relationship because we also aim to investigate the relationship between stakeholders' perception of human-nature relationships and their perception of large carnivores.

\section{Theoretical framework}

\section{Perception of large carnivores}

Historically, little is known about human perceptions of the lynx in NW-Europe. Foxes and wolves, on the other hand, have been intensively persecuted for centuries aiming at complete extermination. Extermination of foxes never succeeded, but-although large scale programs or concerted actions on national levels were absent-the last wolves in NW-Europe were killed at the end of the nineteenth century. Reasons for persecution were the alleged danger to humans and killing of livestock, resulting in hostility towards large carnivores in human history and culture (Chapron et al. 2014; Treves and Karanth 2003).

Previous research suggests several factors to be important in the perception of large carnivores. Firstly, demographic and personal variables influence perceptions. In general, women, the elderly, people with lower education, people living in rural areas and people who do not often recreate in nature have a more negative perception of the wolf and lynx (Røskaft et al. 2003, 2007; Treves and Karanth 2003; Treves et al. 2013). Secondly, certain values and emotions (e.g. security, fear) can have negative effects on the perception of large carnivores, while others (e.g. excitement, curiosity) can have positive effects (Kaltenborn and Bjerke 2002; Røskaft et al. 2007). Third, perceived or experienced risk, personally or economically, also influences perception of large carnivores (Kleiven et al. 2004; Vitters $\varnothing$ et al. 1999). For example, anticipated negative consequences among sheep 
farmers for their livestock result in a more negative perception of wolves, lynx and other large carnivores (Vitters $\emptyset$ et al. 1999). People who already experienced loss because of a large carnivore often have a more negative perception (Naughton-Treves et al. 2003; Røskaft et al. 2007). Someone who has lost a domestic animal to any large carnivore is generally less tolerant towards wolves (Naughton-Treves et al. 2003). These perceptions are linked to the human-carnivore conflict, which is often mitigated by policies such as compensation programs, i.e. enhancing the tolerance of wolves among livestock owners by paying for depredations and in turn help reduce retaliatory killing (Nyhus et al. 2003; Marino et al. 2016). However, studies indicate the ineffectiveness of compensation programs to increase the tolerance for wolf among livestock owners, especially farmers who lost traditional livestock farming practices (Boitani et al. 2010; Marino et al. 2016). Agarwala et al. (2010) showed no change in attitude towards wolves as a result of compensation in the USA and India among rural residents. Additionally, a survey in Sweden indicated that people who are afraid of large carnivores, were less likely to pay for the costs of the human-carnivore conflict (Johansson et al. 2012). These results indicate the need to refine our understandings of public and farmers' perceptions towards conservation management and large carnivores in particular.

Fourthly, familiarity in general influences perception: for instance, being unfamiliar with the lynx negatively affects the perception of this animal (Lescureux et al. 2011). Finally, people with more interest in nature or a more positive perception of nature tend to have a more positive perception of lynx and wolves (Røskaft et al. 2007).

Hunters' perceptions of single and multiple large carnivores are described in several studies (Kellert 1991; Bjerke et al. 1998; Linnell et al. 2000; Ericsson and Heberlein 2003; Naughton-treves et al. 2003; Andersone and Ozolinš 2004; Røskaft et al. 2007; Lüchtrath and Schraml 2015). Most of these studies show that hunters have (more) negative attitudes towards large carnivores (Linnell et al. 2000; Ericsson and Heberlein 2003; Naughtontreves et al. 2003; Røskaft et al. 2007). Linnell and colleagues (2000) explain this from an economic point of view: they argue that because large carnivores compete with hunters who harvest wild ungulates, hunters have negative perceptions of large carnivores. A similar argument can be made for game hunters (Røskaft et al. 2007). Lüchtrath and Schraml (2015) conclude that hunters' negative attitude is a result of defending their social identity. Hunters aim to "upgrade their status" as a group and distinguish themselves from other groups, such as the general public or nature conservationists (Lüchtrath and Schraml 2015). Another argument for the negative perception among hunters could be that wolves may kill their dogs (Naughton-Treves et al. 2003; Røskaft et al. 2007). Conversely, there are also some studies that indicate positive attitudes towards large carnivores (Kellert 1991; Bjerke et al. 1998). The hunters in these studies highly valued "recreational contact with wolf or wilderness areas" and showed little "fear, dislike or indifference toward the wolf" (Bjerke et al. 1998).

\section{Visions of nature}

The stakeholders' visions of nature are relevant to understand the perceptions of large carnivores, and can predict preferred management strategies (Verbrugge et al. 2013). Visions of nature include images of nature, values of nature and images of the humannature relationship (Van den Born 2007). One's image of nature represents what people perceive as nature. Values of nature represent why people believe nature is important. This study focusses on images of the human-nature relationship and uses the so-called Human and Nature scale (HaN scale; Van den Born 2006, 2007) to link the stakeholders' image of 
Table 1 Description of the four classifications of the human-nature relationship (based on Fliervoet et al. 2013)

\begin{tabular}{ll}
$\begin{array}{c}\text { Master over } \\
\text { nature }\end{array}$ & $\begin{array}{c}\text { Humans stand above nature and are allowed to maximize exploitation of nature for the } \\
\text { benefit of human society, as detrimental effects of human actions can easily be } \\
\text { overcome by economic growth and technology. }\end{array}$ \\
$\begin{array}{c}\text { Steward of } \\
\text { nature }\end{array}$ & $\begin{array}{c}\text { Humans stand above nature but have a responsibility to take care of nature towards God } \\
\text { (religious version) or future generations (secular version). }\end{array}$ \\
$\begin{array}{c}\text { Partner with } \\
\text { nature }\end{array}$ & $\begin{array}{c}\text { An equal relationship exists between humans and nature, who work together in a } \\
\text { dynamic process of interaction and mutual development. } \\
\begin{array}{c}\text { Participant in } \\
\text { nature }\end{array}\end{array}$ \\
\hline
\end{tabular}

the human-nature relationship to the stakeholders' perception and preferred management of large carnivores. Based on environmental philosophy (Barbour 1980; Kockelkoren 1993; Zweers 2000), the HaN scale essentially distinguishes four images of the humannature relationship (Table 1): Master over nature, Stewardship of nature, Partnership with nature and Participant in nature (Ganzevoort and Van den Born (2014); Van den Born, 2006, 2007). The HaN scale has been used before in understanding public perceptions, for instance towards non-native species (Verbrugge et al. 2013) and on public support for flood risk management strategies (De Groot 2012).

\section{Methods}

\section{Study area}

The location of the study area (Lingestreek) is shown in Fig. 1. This region is bordered by the lower Rhine River in the north and river Waal in the south and by canals, the Pannerdensch kanaal in the east and Amsterdam-Rijnkanaal in the west. Lingestreek consists of four municipalities: Overbetuwe, Neder-Betuwe, Buren and Lingewaard. The region has approximately 140,000 inhabitants (CBS 2016a). The population density of this region is 358 (pop. $/ \mathrm{km}^{2}$ ) (CBS 2016a, b). Compared to the rest of the Netherlands, this region is not densely populated. The average population density of the Netherlands is $502 \mathrm{pop} . / \mathrm{km}^{2}$ (CBS 2016c). Compared to e.g. Norway, however, it is densely populated because in Norway the average population density is $16 \mathrm{pop} . / \mathrm{km}^{2}$ (Central Intelligence Agency 2016). Lingestreek mainly consists of farmland where arable farming, livestock breeding and horticulture are the main forms of agricultural practice. The area is located in the Province of Gelderland, whose authorities are responsible for nature policies in the area. The provincial government plans and implements Natura 2000 objectives and allocates subsides for nature conservation. Natura 2000 is European legislation to ensure the survival of Europe's most valuable and threatened habitats and species (European Commission 2016). The nature conservation areas in Lingestreek and its surroundings are mainly managed by the State Forestry Service and regional nature conservation organisations. One of these regional organisations is a farmers' association called 'ANV Lingestreek'. This organisation, established by local farmers, combines agricultural activities and nature conservation management. 


\section{Sampling and response rates}

In order to study the perceptions of a large number of people, we followed previous studies by opting for a quantitative research approach (Kaltenborn and Bjerke 2002; Røskaft et al. 2007; Van den Born 2008; Verschuren and Doorewaard 2010). We used a survey to analyse stakeholders' perceptions of their relationship with nature and presence of the fox and the possible establishment of the wolf and lynx. Nature conservationists, scientists and farmers were approached with an online survey. The survey was sent to 106 employees of nature conservation organisations active in Lingestreek via the organisations by which they were employed. This group consisted of both volunteers and professionals, working in different functions and primarily for NGOs. The scientists approached were ecologists and environmental scientists working at nearby universities: Radboud University Nijmegen, Wageningen University and Utrecht University. In total 417 scientists were asked directly (by their email-addresses obtained via the university websites) to fill in the survey. All members of the farmers' association ANV Lingestreek $(N=205)$ received an e-mail to fill in the survey.

Amongst other inhabitants of Lingestreek ("the general public") paper version hard copies of the survey were distributed. The selection of neighbourhoods that are representative for Lingestreek was based on three criteria: (1) geographical spread of respondents within Lingestreek, (2) level of urbanity and (3) level of income of respondents. The Central Bureau for Statistics in the Netherlands distinguishes between five classes of urbanity from 1 (average of 2500 addresses or more per $\mathrm{km}^{2}$ ) to 5 (average of less than 500 addresses per $\mathrm{km}^{2}$ ). In Lingestreek only classes 3, 4 and 5 are present. Based on these criteria six neighbourhoods representative for the area were selected. In these neighbourhoods 1080 surveys (180 in each neighbourhood) were distributed by the first two authors personally. An additional 120 surveys were sent to local volunteers of Lingewaard Natuurlijk, who primarily volunteer in nature education. Hence, in total 1200 surveys were distributed among the general public.

Hunters are an important stakeholder group when researching attitudes towards large carnivores (Andersone and Ozolinš 2004). However, we chose not to include hunters in the survey for two reasons. Firstly, hunting is of little importance in the Netherlands compared to other places, e.g. Scandinavia or the USA. There are few hunters, and hunting is only allowed on a few common species. Wolves and lynx are protected under European legislation in most countries, and hunting them is prohibited (Andersone and Ozolinš 2004). Secondly, hunting is generally a secondary activity to another profession, such as farming. The number of active hunters not involved in farming in Lingestreek is likely negligible and would not justify separate analysis. We did ask respondents whether they are active hunters.

The survey was distributed at the end of March 2015. Farmers, scientists and nature conservationists received an online version of the survey through e-mail which was followed up by a reminder after three weeks. The general public received a hard copy of the survey with pre-stamped return envelopes, but were also offered the opportunity to fill out the online version of the survey if preferred. They did not receive a reminder. Response rate and demographic composition of the stakeholder groups' respondents are listed in Table 2. The response rates were relatively high compared to previous research on nature perceptions in the Netherlands (Vaske et al. 2011). The average age of the respondents of the general public was relatively high (59 years) compared to the average age of adults in Lingestreek (50 years) (CBS 2016a). The education level of farmers and the general public 
Table 2 Overview of response rate and demographic composition of the stakeholder groups

\begin{tabular}{lllll}
\hline & General public & \multicolumn{2}{l}{ Professionals } \\
\cline { 3 - 4 } & & Farmers & Scientists & Nature conservationists \\
\hline Total respondents & 244 & 78 & 113 & 38 \\
Response rate & $20 \%$ & $38 \%$ & $27 \%$ & $35 \%$ \\
Male & $56 \%^{\mathrm{a}}$ & $78 \%$ & $67 \%$ & $92 \%$ \\
Female & $44 \%^{\mathrm{a}}$ & $22 \%$ & $33 \%$ & $8 \%$ \\
Average age; SD (years) & $59 ; 14.5$ & $56 ; 12.3$ & $45 ; 12.4$ & $53 ; 15.2$ \\
Lower education & $5 \%{ }^{\mathrm{b}}$ & $0 \%$ & $0 \%$ & $0 \%$ \\
Average education & $46 \%^{\mathrm{b}}$ & $50 \%$ & $2 \%$ & $21 \%$ \\
Higher education & $49 \%^{\mathrm{b}}$ & $50 \%$ & $98 \%$ & $79 \%$ \\
\hline
\end{tabular}

Lower education was defined as only finishing primary school, not having a degree. Average education was defined as finishing only high school or community college. Higher education was defined as having a college or university degree

${ }^{a}$ General public: $\mathrm{n}=236$

${ }^{\mathrm{b}}$ General public: $\mathrm{n}=233$

is relatively high in our sample, which might reflect a response bias. The percentage of male respondents in the general public is slightly higher than the average of adults in the municipalities, 56\% instead of the expected 50\% (CBS 2016a). Since the general public could fill out the survey on paper, there are some missing values where questions were skipped or multiple answers were chosen. As a result, the general public's number of respondents can differ per question (Table 2).

\section{Questionnaire structure}

In the introductory part of the survey a map of the region was shown to demarcate the study area. The first six to ten questions and statements were stakeholder specific. The general public, for example, was asked how long they had been living in the region and about the composition of their household; farmers were asked after the nature of their agricultural occupation (e.g. arable farming, poultry farming, and/or cattle breeding). The general part started with a question on how often the respondents visited nature areas. Subsequently, the respondents were asked to what extent they agreed with the 17 statements of the Human and Nature (HaN) scale. Each statement represented one of the four images of the humannature relationship, and each relationship was accounted for by four or five statements. One of the participant statements was eliminated during the factor analysis because of a low factor loading (see Table 3 for statements). All statements were directly derived from previous research using the HaN scale (De Groot 2012; Van den Born 2006, 2007), though some of them were slightly reworded to fit this research context. Respondents could react to the statements on a five-point Likert scale: strongly disagree; disagree; neutral; agree; or strongly agree (Flick 2011).

For all respondents, the questionnaire continued with questions and statements concerning the fox, the wolf and the lynx. Each carnivore was briefly introduced with information on its size, appearance (feline or canine) and its presence in the Netherlands and surrounding countries. For the wolf and lynx one question and 17 statements were included, with the same Likert scale as mentioned above to measure level of agreement. 
For the general public the statement "[Foxes, Wolves, Lynx] are a threat to the existence of cattle farms" was excluded because it was not at the time considered relevant to them (supplementary material; Table S-1). The first question was on the estimated chance of establishment in Lingestreek within 15 years, with the options: very small, small, large, very large and I don't know. The 17 statements dealt with perceptions, perceived risks and benefits, and management strategies. The section of the survey concerning the fox started slightly differently from the sections regarding wolf and lynx. The respondent was first asked if they had ever encountered a fox in Lingestreek and, if so, what (predefined) emotions they felt regarding this encounter. Thereafter, the respondents were presented the same 16 or 17 statements as for the wolf and lynx (supplementary material; Table S-1).

The survey concluded with questions for all stakeholder groups regarding gender, age and education level. Additionally, the general public was asked for their postcode in order to measure the level of urbanity. The professionals were asked if they actually lived in the region. Nature conservationists were also asked if they worked in the region, to confirm the assumption that they did. The survey also asked whether someone was an active hunter. This proportion was quite low, $0.5 \%$ of the general public, $1 \%$ of the scientists, and $2.5 \%$ of the nature conservationists. Active hunting was slightly more common among farmers $(10 \%)$.

\section{Data analysis}

Comparison of responses between two stakeholder groups was done with an independent $t$ test; responses of multiple groups were tested using one-way ANOVA. In all cases a confidence interval of $95 \%(\mathrm{p}<0.05)$ was chosen. In case of significant differences, a Games-Howell post hoc test was performed to determine which of the groups differ. Since respondent groups differ in size, no equal variances were assumed. In case of comparing the same question for different carnivores, a paired t-test was performed. When several factors with scale variables were compared simultaneously, a one-way ANOVA was performed, combined with a Games-Howell post hoc test. Linear regressions were performed to check what variables were significant predictors of the perception of large carnivores within stakeholder groups. For nominal variables, nominal logistic regression was performed (Field 2013). All statistical analyses were performed in SPSS version 20 and 21.

Exploratory factor analysis was performed to group the HaN-scale items (Ganzeboom 2013). The HaN-scale statements were recoded from 1 (strongly disagree) to 5 (strongly agree) into -2 (strongly disagree) to 2 (strongly agree). Oblique rotation (Promax) with Kaiser Normalization was used in the factor analysis to allow for correlation between the factors. Items with factor loadings above 0.5 were included in the factor (Field 2013). Respondents for which items were missing were excluded from the analysis. The statement "In the mountains, I feel the insignificance of mankind”, originally referring to the participant relationship, did not fit any of the factors and was therefore excluded from further analyses.

\section{Results}

\section{Visions of Nature}

The factor analysis $(\mathrm{N}=449)$, resulted in three factors. Most statements originally meant to indicate partner and participant positions were combined into a new partner/participant 
Table 3 Clustering of HaN-scale statements into factors representing images of the human-nature relationships $(\mathrm{N}=449)$

\begin{tabular}{|c|c|c|c|c|}
\hline & $\begin{array}{l}\text { Original image of } \\
\text { relationship }\end{array}$ & $\begin{array}{l}\text { Factor } \\
\text { loading }\end{array}$ & Mean & $\begin{array}{l}\text { Standard } \\
\text { deviation }\end{array}$ \\
\hline \multicolumn{5}{|l|}{ Master } \\
\hline Nature should not hamper economic progress & Master & 0.729 & -0.56 & 0.966 \\
\hline The ability to think puts humans above nature & Master & 0.726 & -0.38 & 1.063 \\
\hline Nature is there for me, not the other way around & Master & 0.646 & -0.19 & 1.112 \\
\hline \multirow{2}{*}{$\begin{array}{l}\text { We have the right to change nature if humans } \\
\text { benefit from it }\end{array}$} & Master & 0.619 & -0.16 & 0.953 \\
\hline & Mean of the factor & & -0.31 & 0.739 \\
\hline \multicolumn{5}{|l|}{ Steward } \\
\hline $\begin{array}{l}\text { Our generation has to take care that nature will be } \\
\text { preserved for future generations }\end{array}$ & Steward & 0.744 & 1.49 & 0.555 \\
\hline $\begin{array}{l}\text { Because humans have the ability to think, we } \\
\text { should take care of nature }\end{array}$ & Steward & 0.713 & 1.22 & 0.704 \\
\hline $\begin{array}{l}\text { Every human being is responsible for the } \\
\text { conservation of nature }\end{array}$ & Steward & 0.619 & 1.13 & 0.630 \\
\hline $\begin{array}{l}\text { We are part of nature and therefore we are } \\
\text { responsible to take care of it }\end{array}$ & Steward & 0.568 & 1.09 & 0.651 \\
\hline I feel obliged to protect nature & Steward & 0.560 & 0.93 & 0.686 \\
\hline $\begin{array}{l}\text { Human beings are inextricably connected with } \\
\text { nature }\end{array}$ & Participant & 0.517 & 1.23 & 0.688 \\
\hline \multirow{2}{*}{$\begin{array}{l}\text { Nature should be given the possibility to develop, } \\
\text { just like humans }\end{array}$} & Partner & 0.515 & 0.99 & 0.735 \\
\hline & Mean of the factor & & 1.15 & 0.436 \\
\hline \multicolumn{5}{|l|}{ Partner/participant } \\
\hline Humans and nature are of equal value & Partner & 0.734 & 0.35 & 0.982 \\
\hline $\begin{array}{l}\text { Humans and nature are entitled to an equal } \\
\text { consideration }\end{array}$ & Partner & 0.725 & 0.69 & 0.925 \\
\hline I feel at one with all life on earth & Participant & 0.691 & 0.76 & 0.841 \\
\hline $\begin{array}{l}\text { The relationship of humans with nature defines } \\
\text { who we are }\end{array}$ & Participant & 0.566 & 0.72 & 0.840 \\
\hline \multirow[t]{2}{*}{ I consider nature as a good friend } & Partner & 0.523 & 0.89 & 0.715 \\
\hline & Mean of the factor & & 0.68 & 0.615 \\
\hline
\end{tabular}

factor. All master statements were indeed clustered by the factor analysis into the factor master over nature. The factor designated as steward comprises all steward statements, but also two statements originally meant to represent the partner and participant positions respectively (Table 3). The factor loadings in Table 3 show to what extent the statement fits the factor. The given mean is the mean of the responses across all respondents of all stakeholder groups and runs from -2 (strongly disagree) to 2 (strongly agree).

The mean level of adherence for each factor was calculated per stakeholder group (Table 4). All stakeholder groups disagree (strongly) with the master factor except for the farmers and all stakeholder groups generally agree with the statements representing the steward and the partner/participant. A one-way ANOVA comparing adherence to the factors among different stakeholder groups show significant differences within each factor $\quad(F($ master $)=31.777, \quad p=0.000), \quad(F($ steward $)=9.859, \quad p=0.000) \quad$ and 
Table 4 Adherence of the four stakeholder groups to the images of the human-nature relationship. The mean runs from -2 (strongly disagree) to 2 (strongly agree). A negative mean thus implies disagreement with the factor

\begin{tabular}{|c|c|c|c|c|c|c|c|c|c|c|}
\hline & \multicolumn{2}{|c|}{$\begin{array}{l}\text { Combined } \\
(\mathrm{n}=449)\end{array}$} & \multicolumn{2}{|c|}{$\begin{array}{l}\text { General public } \\
(\mathrm{n}=220)\end{array}$} & \multicolumn{2}{|c|}{$\begin{array}{l}\text { Farmers } \\
(\mathrm{n}=78)\end{array}$} & \multicolumn{2}{|c|}{$\begin{array}{l}\text { Scientists } \\
(\mathrm{n}=113)\end{array}$} & \multicolumn{2}{|c|}{$\begin{array}{l}\text { Conservationists } \\
(\mathrm{n}=38)\end{array}$} \\
\hline & $\mu$ & SD & $\mu$ & $\mathrm{SD}$ & $\mu$ & SD & $\mu$ & SD & $\mu$ & SD \\
\hline Master & -0.31 & 0.739 & -0.22 & 0.656 & 0.14 & 0.782 & -0.75 & 0.631 & -0.63 & 0.667 \\
\hline Steward & 1.15 & 0.436 & 1.14 & 0.403 & 0.95 & 0.494 & 1.27 & 0.407 & 1.28 & 0.443 \\
\hline Partner/participant & 0.68 & 0.615 & 0.70 & 0.590 & 0.52 & 0.613 & 0.66 & 0.640 & 0.87 & 0.638 \\
\hline
\end{tabular}

$(\mathrm{F}($ partner/participant $)=3.741, \mathrm{p}=0.011)$. A Games-Howell post hoc test shows that farmers agree significantly more with statements supporting master over nature than nature conservationists $(\mathrm{p}=0.000)$, scientists $(\mathrm{p}=0.000)$ and the general public $(\mathrm{p}=0.002)$. Nature conservationists $(\mathrm{p}=0.005)$ and scientists $(\mathrm{p}=0.000)$ reject master over nature statements significantly more than the general public. Farmers, however, agree significantly less with the partner/participant than nature conservationists $(p=0.035)$ and the general public $(\mathrm{p}=0.030)$ and also significantly less with the steward statements than nature conservationists $(\mathrm{p}=0.004)$, scientists $(\mathrm{p}=0.000)$ and the general public $(\mathrm{p}=0.017)$. All groups agree with the steward of nature most, and the master over nature least.

\section{Perceptions regarding large carnivores}

The perceptions of the different carnivores per stakeholder group are shown in Fig. 2. We used the statement "I feel positive towards the presence of the [fox, wolf, lynx] in Lingestreek" to measure a general perception. All stakeholder groups are significantly more positive towards the presence of the fox, than towards the presence of the wolf and the lynx in Lingestreek (supplementary material; Table S-2). Only the scientists were significantly more positive towards the lynx than towards the presence of the wolf $(\mathrm{t}=-2.579$; $\mathrm{p}=0.011$ ); among the other stakeholder groups no statistical differences between the wolf and lynx were found. Similar patterns are found in other statements, like "[Foxes, Wolves, Lynx] do not belong in Lingestreek" (supplementary material; Figure S-1). Based on a regression analysis, adherence to the mastery over nature relationship predicts a negative perception regarding the fox $(\beta=-0.409 ; \mathrm{p}=0.000)$, the wolf $(\beta=-0.430 ; \mathrm{p}=0.000)$ and the lynx $(\beta=-0.391 ; \mathrm{p}=0.000)$.

\section{Large carnivore management}

Respondents were asked to what extent they agree with several statements regarding large carnivore management. The results of three of these are described in this paragraph. Regarding the chance of establishment of the wolf in Lingestreek within 15 years, $72 \%$ of the respondents estimated the chance (very) low, and $12.5 \%$ of the respondents answered that they did not know. Regarding the lynx, 79\% of the respondents estimated the chance of establishment to be (very) low, 15\% did not know. A regression analysis shows that among scientists and the general public it appears that a higher estimation of the chance of establishment for wolf $\left(\beta_{\text {scientist }}=0.409 ; p_{\text {scientist }}=0.000\right.$. $\mathrm{B}_{\text {general public }}=0.258 ; \mathrm{p}_{\text {gen- }}$ eral public $=0.000)$ predicts a more positive perception of the wolf. A higher estimation of 

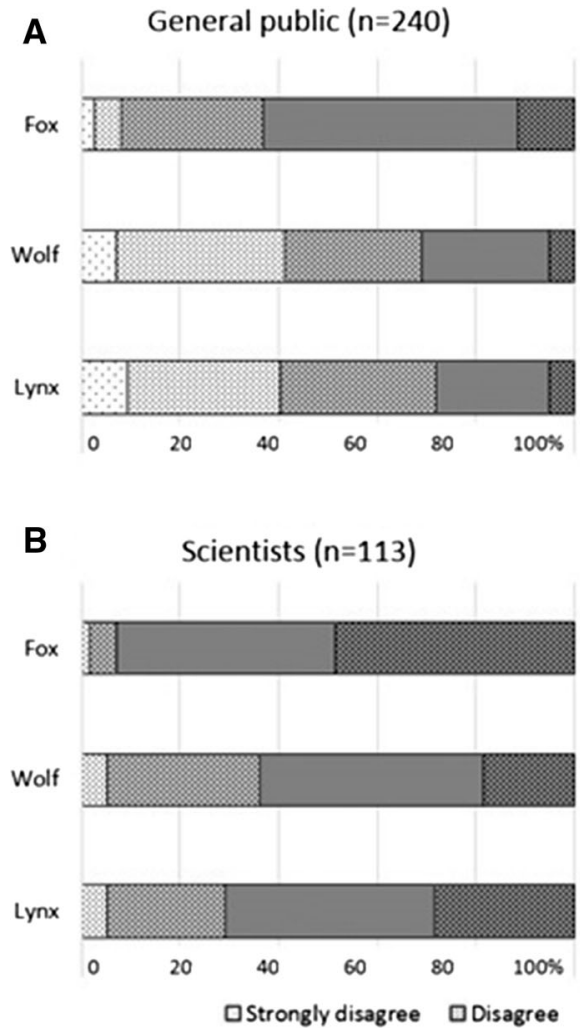

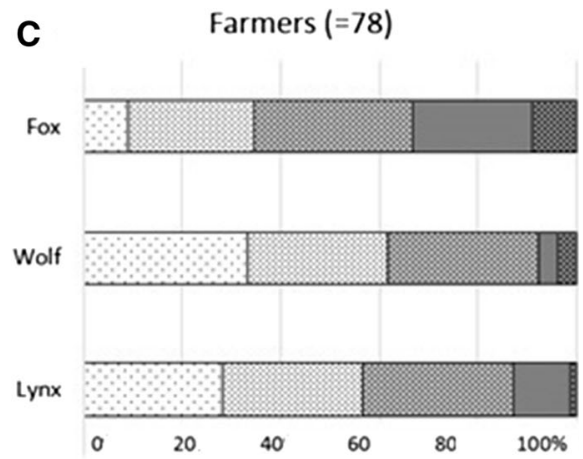

D Nature conservationists $(\mathrm{n}=38)$

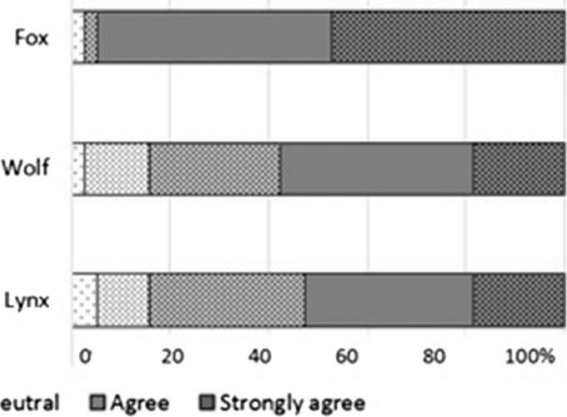

Fig. 2 Perceptions of the stakeholder groups towards the presence of the different large carnivores in Lingestreek expressed in the level of agreement to the statement: "I feel positive towards the presence of the [fox, wolf, lynx] in Lingestreek"

the chance of establishment for the lynx predicts a more positive perception of the lynx among nature conservationists ( $\beta_{\text {nature conservationists }}=0.363 ; p_{\text {nature conservationists }} 0.032$ ) and the general public $\left(\beta_{\text {general public }}=0.266 ; p_{\text {general public }}=0.000\right)$.

Regarding the statement "Foxes should be shot if they kill pets or livestock" (Fig. 3a), a one-way ANOVA $(\mathrm{F}=34.820, \mathrm{p}=0.000)$ with Games-Howell post hoc shows that nature conservationists $(\mu=2.74, \mathrm{SD}=1.083)$ did not differ significantly from scientists $(\mu=2.74, \mathrm{SD}=0.920, \mathrm{p}=0.296)$ and the general public $(\mu=3.05, \mathrm{SD}=1.013$, $\mathrm{p}=0.349)$, but they did differ significantly from farmers $(\mu=3.88, \mathrm{SD}=1.081$, $\mathrm{p}=0.000$ ). This pattern is seen for shooting of the wolf and lynx as well (Figs. 3b and 3c), but here it was not statistically significant. The clustering of nature conservationists with general public and scientists is seen with other management measures as well (supplementary material; Figures S-4 and S-5). Farmers were significantly more in favour of compensating damage due to all three species than the general public, nature conservationists and scientists (supplementary material; Table S-3). A one-way ANOVA $(\mathrm{F}=11.966, \mathrm{p}=0.000)$ with Games-Howell post hoc shows that the general public $(\mu=3.20, \mathrm{SD}=0.938)$ was significantly more in favour of compensating damage due to foxes than scientists $(\mu=2.90, \mathrm{SD}=1.000, \mathrm{p}=0.042) \quad$ (supplementary material; 
A

Fox

General public ( $n=238$ )

Farmer $(n=78)$

Scientists $(n=113)$

Nature conservationists ( $n=38$ )

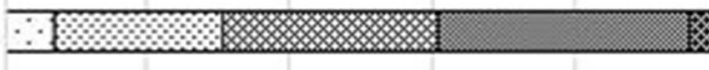

B

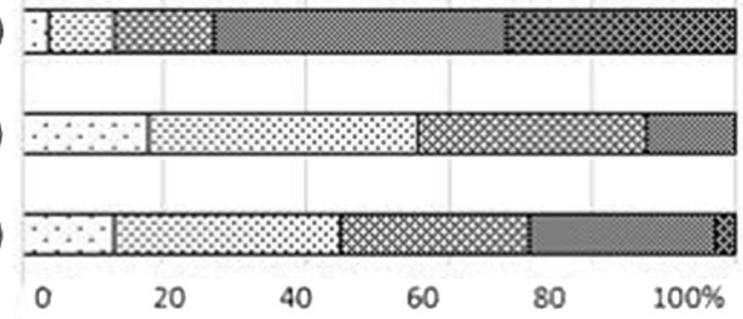

\section{Wolf}

General public ( $n=237)$

Farmer $(n=78)$

Scientigs $(n=113)$

Nature conservationists $(n=38)$
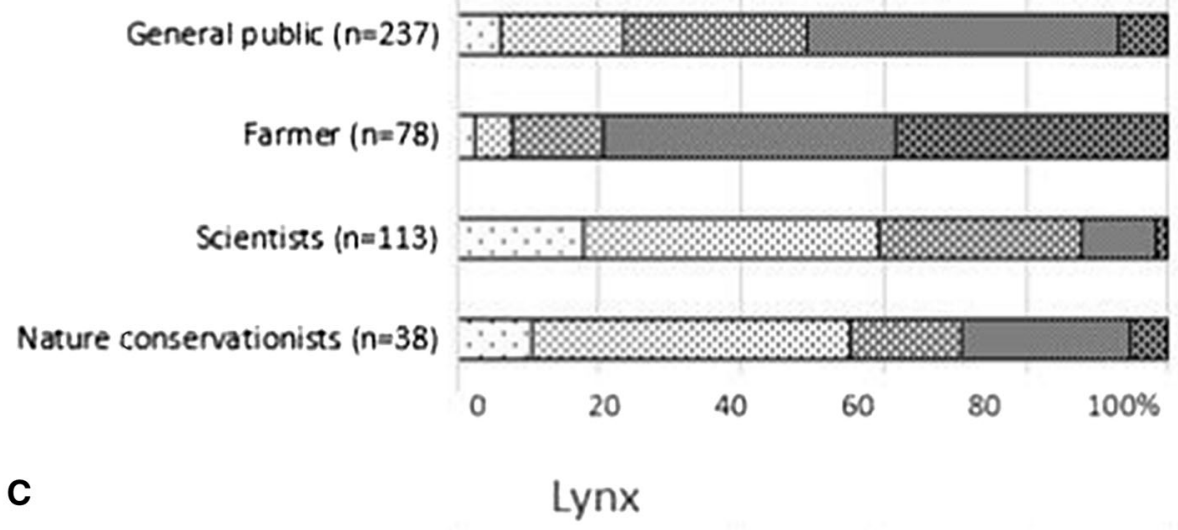

General public ( $n=235$ )

Farmer $(n=78)$

Scientists $(n=113)$

Nature conservationists $(n=38)$

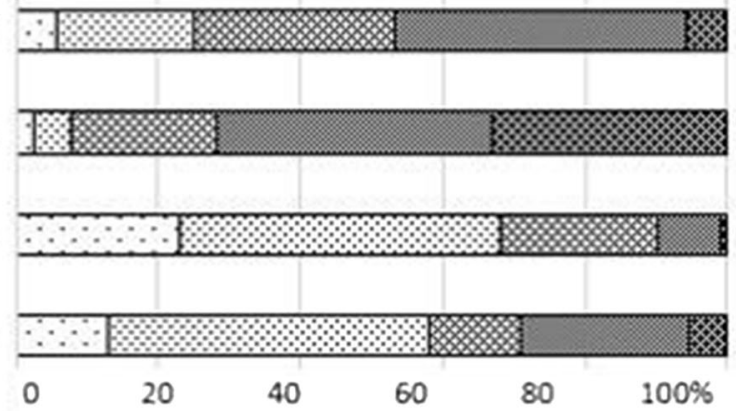

\section{$\square$ Strongly disagree $\square$ Disagree $\square$ Neutral $\square$ Agree $\square$ Stronglyagree}

Fig. 3 The extent to which the different stakeholder groups agree with the statement: "[Foxes, Wolves, Lynx] should be shot if they kill pets or livestock"

Figure S-2a). Regarding the compensation for damage caused by the wolf and the lynx, no significant differences were found between the general public, nature conservationists and scientists (supplementary material; Figure S-2b and S-2c). 
Among the general public 70-80\% (strongly) agrees with the statement "I trust nature conservationists to make the right decisions in managing foxes/wolves/lynx in Lingestreek" (supplementary material; Figure S-3). Together with the scientists (70-75\%), the general public have the highest trust in nature conservationists. Farmers appeared to have the least trust in nature conservationists. Regarding these statements nature conservationists have less trust in the decision making of the organisations they represent than scientists and the general public. A one-way ANOVA $(\mathrm{F}=11.097, \mathrm{p}=0.000)$ shows that nature conservationists $(\mu=3.21, \mathrm{SD}=1.018)$ have significantly less trust in nature conservationists to make the right decisions in management of foxes than scientists $(\mu=3.73, \mathrm{SD}=0.744, \mathrm{p}=0.026)$ and the general public $(\mu=3.78, \mathrm{SD}=0.708$, $\mathrm{p}=0.009)$.

\section{Discussion}

We analysed the perceptions of scientists, nature managers, farmers and the general public regarding the presence of the fox and the possible establishment of the wolf and lynx in Lingestreek. The response rates were relatively high compared to previous research on nature perceptions in the Netherlands (Vaske et al. 2011). One-fifth of the general public responded, $38 \%$ of the farmers, $27 \%$ of the scientists and $35 \%$ of the nature conservationists. A possible reason for this relatively high response may have been the coincidental visit of a wolf in the northern part of the Netherlands, precisely in the month the surveys were distributed. Although the wolf was not seen in the study area itself, his occurrence triggered public debate on large carnivore management in the Netherlands (Drenthen 2015).

The study area Lingestreek is representative for Dutch rural areas, but is more urban than other rural areas in Europe. Our study covered a largely representative sample of the stakeholder groups. The nature conservationists formed the smallest respondents group because of the small number of them actually working in the area. Moreover, some of them are non-professionals residing in the area and volunteering in conservation work. This may also have influenced the results, since they may have strong personal connections with farmers and the general public. Differences between nature conservationists and farmers or the general public may therefore even be more pronounced if these volunteers had not been included. The farmers were contacted through a farmers' association, which is established by local farmers and combines agricultural activities and nature conservation. As a result, these farmers might be more nature-minded and thus more positive towards large carnivores than the average Dutch farmer.

\section{Visions of nature}

The results indicate that one's human-nature relationship can influence the perception of large carnivores and the preferred management strategy. The original partner with nature and participant in nature images were not recognized as separate positions by the respondents. Instead, both positions merged into one new category in the factor analysis. Partnership represents an equal relationship with nature while participation refers to humans being part of nature. Apparently, respondents in general do not clearly see differences between these positions. Previous quantitative research also showed similarities in the adherence to the partner with nature and participant in nature relationship (De Groot 
et al. 2011; Ganzevoort and Van den Born, 2014; Verbrugge et al. 2013). In qualitative research, however, respondents do distinguish between partner and participant positions (Van den Born 2008).

The results show that all stakeholder groups have the highest adherence to the steward of nature and the lowest to the master over nature relationship. This is consistent with previous research on the public's Human and Nature relationship (Van den Born 2006; Verbrugge et al. 2013). People adhering to a master over nature relationship feel that humans stand above nature and can exploit nature for human benefit. However, the master over nature relationship is not a position that people are generally attracted to (Van den Born 2006, 2007). In qualitative research, arguments given to reject the master over nature are 'humans should not stand above nature' and 'humans are not superior to nature' (Van den Born 2008). The fact that farmers, compared to other stakeholder groups, were more positive towards the master over nature may be explained by their dependency on managing and controlling their land for their livelihood (cf. Natori and Chenoweth 2008). This may also be the reason why adherence to the master over nature relationship predicts a negative perception of large carnivores, as shown by the regression analysis.

\section{Perceptions regarding large carnivores}

In our study, nature conservationists and scientists have the most pronounced positive perception regarding large carnivores, which is in line with the findings of Kaltenborn and Bjerke (2002). They related life values to attitudes regarding large carnivores among sheep farmers, wildlife biologists and research biologists in Norway. They found that a positive attitude is related to ecocentric values and values like curiosity and excitement. Another reason why scientists are more positive towards large carnivores could be that-in general-they do not live in the area, and thus view potential conflicts from a more distant, non-involved position. Furthermore, they may take a more romantic stance towards large carnivores, despite their scientific background. In contrast, it is also possible that they view the conflict from a non-emotional, 'rational' perspective taking into consideration benefits of improved ecosystem functioning. The more negative perception of farmers is easier to interpret and could be a direct result from the impact large carnivores may have on their livelihood (Naughton-Treves et al. 2003). Kaltenborn and Bjerke (2002) showed that this might be related to possible damage to their livestock, and related to values like security and tradition. These negative perception of farmers should be taken into account when formulating new polices and compensation programs, especially for farmers in areas where traditional livestock practices have largely been lost (Marino et al. 2016).

Among the general public there are more respondents with a negative perception of wolves and lynxes than respondents with a positive perception. One reason for this could be that the study area is relatively rural; studies indicate that people living in rural areas have a more negative perception of large carnivores than people living in urban areas (Røskaft et al. 2007; Treves et al. 2013). Citizens in rural areas are more likely to experience conflict with large carnivores than people living in urban areas (Naughton-Treves et al. 2003; Røskaft et al. 2007). Lescureux et al. (2011) show a negative perception of the lynx in Macedonia due to unfamiliarity with the carnivore. Either this unfamiliarity with large carnivores (especially lynx) or the malicious role they play in fairy tales and stories (especially wolves) may be additional explanations for the more negative perception of the general public of the lynx and wolf, compared with the fox of which people have more factual knowledge. 


\section{Large carnivore management}

Farmers agreed more with all statements favouring management strategies reducing the impact of large carnivores than the other stakeholder groups. This is not surprising given the perception that their livelihood is directly influenced by the management strategy chosen, and is in line with their relatively negative perception of large carnivores. Also Kovařík and colleagues (2014) showed that sheep farmers expressed the need for financial compensation from attacks on sheep by large predators in the Czech Republic. An innovative Swedish strategy involved providing incentives for human-carnivore coexistence. This strategy focused on paying reindeer herders based on the number of documented wolverine reproductions in their district (Persson et al. 2015). However, the current compensation strategies used in Italy, USA and India (linked to the damage inflicted) do not seem to increase the tolerance for large predators (Boitani et al. 2010; Agarwala et al. 2010; Marino et al. 2016). In our study, farmers also agree more often with the master statements, implying that they are more in favour of controlling and managing nature, see also Ahnström et al. (2009) and Nordström Källström and Ljung (2005). Scientists were generally against intensive management of large carnivores, and rejected the master over nature relationship; as such, they may therefore not be too supportive of human influence on nature. Alternatively, they may view large carnivores from an ecosystem point of view and consider them to be important for an ecosystem to sustain itself ( $c f$. Kaltenborn et al. 1999). Finally, the aforementioned observation that most scientists do not live within the study area may also reduce the perceived need for active management.

Nature conservationists hold an intermediate position concerning management of large carnivores, possibly because they have to take into account interests of other stakeholder groups. By virtue of their function, nature conservationists have to deal with trade-offs regarding management costs. They often seek contact with the general public, farmers and others stakeholders to find out which trade-offs the stakeholders will support (LeaderWilliams et al. 2010), and may therefore have more insight and empathy regarding other parties' visions of nature. The nuanced response might also be a result of the variety of local, regional and national nature organisations in the survey. Each of them has a different vision on how nature should be managed. Some tend to focus on creating "wild nature" while others try to conserve a balance between nature and cultural heritage. Other research confirms the idea that stakeholders can hold different images of the landscape; wolf supporters, for example, often associate an environment with wilderness while farmers envision the same environment as "a landscape for sustainable use" (Buijs et al. 2012).

It is remarkable that the group of nature conservationists showed the least trust in the organisations they are employed by and are supposed to represent. This might also result from the variety of nature conservation organisations involved in the survey. Because they have different goals, they operate based on different ideals and assumptions, which might result in conflicting frames about how problems are defined or should be solved with regard to carnivore management (Clark et al. 1996). It can also reflect differences of opinion between central bureaus responsible for policy development and regionally based offices of the same organisation in charge with actual management measures in the field, where they are confronted with local concerns that do not match central policies-also known as the planning-implementation gap (Biggs et al. 2011). Another reason could be that some respondents in the group of nature conservationists were volunteers who might not identify themselves with a particular nature conservation organisation, but who are fully aware of conservation organisations' policies and goals. 


\section{Implications for conservation}

This research shows the importance of distinguishing among divergent stakeholder groups involved in or confronted with large carnivore management. Significant differences were found among stakeholder groups regarding their visions of nature, perception of large carnivores and management preferences. It is worthwhile to also study perceptions of other stakeholder groups involved, such as policy makers. In addition, in countries where hunters are a significant stakeholder group, it is important to take their attitudes into account. Generally, they have a negative attitude towards large carnivores and this can strongly influence the debate (Lüchtrath and Schraml 2015).

Taking the full spectrum of stakeholder groups into account would improve understanding of large carnivore perceptions and improve the process of choosing among different management options. This is especially important when the interests of both nature and society need to be served within a limited space and risks of conflicts are substantial. Making stakeholders' visions of nature and perceptions of large carnivores explicit also contributes to mutual understanding amongst stakeholders and consequently to more fruitful debates on different management strategies and implications. Additionally, differences within groups should also be explored to understand how conservation management is implemented. For example, Reimer et al. (2012) identified three types of farmers based on their environmental attitudes: farm as business, off-farm environmental benefits, and stewardship. The latter two types of famers were most likely to adopt conservation practices in the USA (Reimer et al. 2012).

Visions of nature appeared to be predictive of perceptions of large carnivores, as-for all stakeholder groups - a correlation is found between adherence to master and a negative perception of large carnivores. This is also relevant when discussing desired strategies for conservation management. It is important to realize that the main vision one endorses does not necessarily match practical behaviour. Moreover, Verbrugge et al. (2013) argue that the predictive value of images of human-nature relationships for perception regarding nonnative species remains low. The above arguments and our results indicate that a participant or steward perspective on the relationship between humans and nature does not necessarily imply a positive perception of large carnivores.

Distinguishing between diverse stakeholder groups has also practical implications. Our results highlight the importance of different perceptions when trying to involve different stakeholder groups in nature conservation. Our study indicates, for example, that it will be relatively difficult to find common ground between farmers and scientists because of their largely conflicting perceptions. Nature conservationists and policy makers should take into account these pluralistic perceptions in their modes of communication, which is also addressed by Sandström et al. (2015). Moreover, for communication purposes, it is noticeable that our study showed that all respondent groups are to some degree positive regarding the steward position. As mentioned earlier, Reimer et al. (2012) indicated that farmers who identified responsibilities to others (stewardship) were most likely to adopt conservation practices. Framing messages from a steward point of view may provide ground for stakeholder groups to understand each other and agree on a set of goals for carnivore management, but more social science research is needed to probe this idea. Additionally, if stakeholder groups are unfamiliar with a species (e.g. wolf or lynx), providing them with factual information on carnivore ecology and behaviour and relating it to species people are familiar with (e.g. the fox) could lead to a more positive perception (Lescureux et al. 2011). 
Sjölander-Lindqvist et al. (2015) identified five concepts that need to be taken into account regarding large carnivore governance and management: (1) establishment of trust between people and groups interacting on the subject; (2) fair representation of stakeholder interests; (3) acknowledgement of the different knowledge-spheres, including those based on personal experiences, culture and tradition, and science; (4) communication, based on dialogue about pluralistic perspectives, to find common ground; (5) emphasising empowerment. Our results emphasize the importance of involving diverse stakeholders, because of their different perceptions towards large carnivores, compensation measures and large carnivore management in general. Moreover, we argue that communication (concept 4) could be improved and enriched by explicitly working with the diversity of visions of nature held by the stakeholders.

\section{Conclusion}

The presence of the fox and possible establishment of the wolf and lynx can generally count on neutral to positive perceptions of scientists, nature managers, the general public and-to some level-even farmers, even though this was not expected beforehand for all stakeholder groups. Our findings also show the usefulness of distinguishing between different stakeholder groups regarding their perception of large carnivores. People actually living in the study area (farmers and the general public) have a less positive attitude towards large carnivores than scientists and nature conservationists, possibly resulting in less support for large carnivores and a higher level of perception of risks with regard to domestic animals, which would also encompass poultry and other species.

Additionally, the stakeholders' vision of nature, based on their perception of the human-nature relationship, indicates a wide range of perceptions within and among stakeholder groups. Farmers showed the highest level of adherence to the master over nature position, but all stakeholder groups agreed most with the stewardship statements. These findings provide insights for carnivore management and guidelines for communication about large carnivores. Moreover, the adherence to the stewardship position (humans stand above nature but have a responsibility to take care of nature) could be a connecting factor to find common ground in discussions on how to deal with large carnivores in human-dominated landscapes.

Open Access This article is distributed under the terms of the Creative Commons Attribution 4.0 International License (http://creativecommons.org/licenses/by/4.0/), which permits unrestricted use, distribution, and reproduction in any medium, provided you give appropriate credit to the original author(s) and the source, provide a link to the Creative Commons license, and indicate if changes were made.

\section{References}

Agarwala M, Kumar S, Treves A, Naughton-Treves L (2010) Paying for wolves in Solapur, India and Wisconsin, USA: comparing compensation rules and practice to understand the goals and politics of wolf conservation. Biol Conserv 143(12):2945-2955

Ahnström J, Höckert J, Bergeå HL, Francis CA, Skelton P, Hallgren L (2009) Farmers and nature conservation: what is known about attitudes, context factors and actions affecting conservation? Renew Agric Food Syst 24(01):38-47

Andersone Z, Ozolinš J (2004) Public perception of large carnivores in Latvia. Ursus 15(2):181-187

Barbour IG (1980) Technology, environment, and human values. Preager Publishers, New York 
Bath A, Olszanska A, Okarma H (2008) From a human dimensions perspective, the unknown large carnivore: public attitudes toward Eurasian Lynx in Poland. Hum Dimens Wildl 13(1):31-46

Bhattacharjee A, Parthasarathy N (2013) Coexisting with large carnivores: a case study from Western Duars, India. Hum Dimens Wildl 18(1):20-31

Biggs D, Abel N, Knight AT, Leitch A, Langston A, Ban NC (2011) The implementation crisis in conservation planning: could "mental models" help? Conserv Lett 4(3):169-183

Bjerke T, Reitan O, Kellert SR (1998) Attitudes toward wolves in southeastern Norway. Soc Nat Resour 11(2):169-178

Boitani L, Ciucci P, Raganella-Pelliccioni E (2010) Ex-post compensation payments for wolf predation on livestock in Italy: a tool for conservation? Wildl Res 37(8):722-730

Bruskotter JT, Shelby LB (2010) Human dimensions of large carnivore conservation and management: introduction to the special issue. Hum Dimens Wildl 15(5):311-314

Buijs A, Hovardas T, Figari H, Castro P, Devine-Wright P, Fischer A, Mouro C, Selge S (2012) Understanding people's ideas on natural resource management: research on social representations of nature. Soc Nat Resour 25(11):1167-1181

CBS (2016a) Statline. Statistics Netherlands. http://statline.cbs.nl/Statweb/publication/?DM=SLNL\&PA= 03759ned \&D1=0-2\&D2=0,19-96,129\&D3=181,449,523,601\&D4=27-28\&HDR=T,G1,G3\&STB= G2\&VW=T. Accessed Nov 2016

CBS (2016b) Statline. Statistics Netherlands. http://statline.cbs.nl/Statweb/publication/?DM=SLNL\&PA= 70262 ned $\& D 1=0,2,6,16,20,25,28,31,41 \& D 2=211,439,498,559 \& D 3=3-6 \& H D R=T, G 1 \& S T B=$ G2\&VW=T. Accessed Nov 2016

CBS (2016c) Statline. Statistics Netherlands. http://statline.cbs.nl/Statweb/publication/?DM=SLNL\&PA= 37296ned\&D1=68\&D2=0,10,20,30,40,50,(1-1)-1\&VW=T. Accessed Nov 2016

Central Intelligence Agency (2016) Norway in The World Factbook, Washington DC. https://www.cia.gov/ library/publications/the-world-factbook/geos/print/country/countrypdf_no.pdf. Accessed June 2016

Chapron G, Kaczensky P, Linnell JDC, von Arx M, Huber D, Andrén H, López-Bao JV, Adamec M, Álvares F, Anders O, Balčiauskas L, Balys V, Bedő P, Bego F, Blanco JC, Breitenmoser U, Brøseth H, Bufka L, Bunikyte R, Ciucci P, Dutsov A, Engleder T, Fuxjäger C, Groff C, Holmala K, Hoxha B, Iliopoulos Y, Ionescu O, Jeremić J, Jerina K, Kluth G, Knauer F, Kojola I, Kos I, Krofel M, Kubala J, Kunovac S, Kusak J, Kutal M, Liberg O, Majić A, Männil P, Manz R, Marboutin E, Marucco F, Melovski D, Mersini K, Mertzanis Y, Mysłajek RW, Nowak S, Odden J, Ozolins J, Palomero G, Paunović M, Persson J, Potočnik H, Quenette P-Y, Rauer G, Reinhardt I, Rigg R, Ryser A, Salvatori V, Skrbinšek T, Stojanov A, Swenson JE, Szemethy L, Trajçe A, Tsingarska-Sedefcheva E, Váňa M, Veeroja R, Wabakken P, Wölfl M, Wölfl S, Zimmermann F, Zlatanova D, Boitani L (2014) Recovery of large carnivores in Europe's modern human-dominated landscapes. Science 346(6216):1517-1519

Clark TW, Curlee AP, Reading RP (1996) Crafting effective solutions to the large carnivore conservation problem. Conserv Biol 10:940-948

Czarnomska SD, Jędrzejewska B, Borowik T, Niedziałkowska M, Stronen AV, Nowak S, Mysłajek RW, Okarma H, Konopiński M, Pilot M, Śmietana W, Caniglia R, Fabbri E, Randi E, Pertoldi C, Jędrzejewski W (2013) Concordant mitochondrial and microsatellite DNA structuring between Polish lowland and Carpathian Mountain wolves. Conserv Genet 14(3):573-588

De Groot M (2012) Exploring the relationship between public environmental ethics and river flood policies in western Europe. J Environ Manag 93(1):1-9

De Groot M, Drenthen M, De Groot WT (2011) Public visions of the human/nature relationship and their implications for environmental ethics. Environ Ethics 33(1):25-44

Drenthen M (2014) The wolf is coming! Emplacing a predator that is not (yet) there. In: Drenthen M, Keulartz J (eds) Old world and new world perspectives in environmental philosophy. Transatlantic conversations. Springer, Berlin, pp 153-174

Drenthen M (2015) The return of the wild in the anthropocene. Wolf resurgence in the Netherlands. Ethics Policy Environ 18(3):318-337

Enserink M, Vogel G (2006) The carnivore comeback. Science 314:746-749

Ericsson G, Heberlein TA (2003) Attitudes of hunters, locals, and the general public in Sweden now that the wolves are back. Biol Conserv 111(2):149-159

European Commission (2016) Natura 2000. http://ec.europa.eu/environment/nature/natura2000/index_en. htm. Accessed 19 Feb 2016

Field A (2013) Discovering statistics using IBM SPSS statistics. Sage, London

Flick U (2011) Introducing research methodology: a beginner's guide to doing a research project. Sage, London

Fliervoet JM, Van den Born RJG, Smits AJM, Knippenberg L (2013) Combining safety and nature: a multistakeholder perspective on integrated floodplain management. J Environ Manag 128:1033-1042 
Frank J, Johansson M, Flykt A (2015) Public attitude towards the implementation of management actions aimed at reducing human fear of brown bears and wolves. Wildl Biol 21(3):122-130

Galaverni M, Caniglia R, Fabbri E, Milanesi P, Randi E (2016) One, no one, or one hundred thousand: how many wolves are there currently in Italy? Mamm Res 61(1):13-24

Ganzeboom H (2013) Stappenplan Factoranalyse. http://www.harryganzeboom.nl/Teaching/stappenplan_ factoranalyse.pdf. Accessed 18 Dec 2014

Ganzevoort W, Van den Born RJG (2014) Exploring place attachment and visions of nature of water-based recreationists: The case of the longitudinal dams. Landscape Research

Glikman JA, Frank B (2011) Human dimensions of wildlife in Europe: the Italian way. Hum Dimens Wildl 16(5):368-377

Glikman JA, Vaske JJ, Bath AJ, Ciucci P, Boitani L (2012) Residents' support for wolf and bear conservation: the moderating influence of knowledge. Eur J Wildl Res 58(1):295-302

Johansson M, Sjöström M, Karlsson J, Brännlund R (2012) Is human fear affecting public willingness to pay for the management and conservation of large carnivores? Soc Nat Resour 25(6):610-620

Kaczensky P, Chapron G, von Arx M, Huber D, Andrén H, Linnell J (eds) (2012) Status, management and distribution of large carnivores - bear, lynx, wolf \& wolverine - in Europe. http://ec.europa.eu/ environment/nature/conservation/species/carnivores/pdf/task_1_part1_statusoflcineurope.pdf. Accessed 22 June 2016

Kaltenborn BP, Bjerke T (2002) The relationship of general life values to attitudes toward large carnivores. Hum Ecol Rev 9(1):55-61

Kaltenborn BP, Bjerke T, Vitters $\varnothing$ J (1999) Attitudes toward large carnivores among sheep farmers, wildlife managers, and research biologists in Norway. Hum Dimens Wildl 4(3):57-73

Kellert SR (1991) Public views of wolf restoration in Michigan. In: Transactions of the 56th North American wildlife and natural resources conference. Wildlife Management Institute, Washington, DC, $152-161$

Kleiven J, Bjerke T, Kaltenborn B (2004) Factors influencing the social acceptability of large carnivore behaviours. Biodivers Conserv 13(9):1647-1658

Kockelkoren PJH (1993) De vernieuwing van Nederland [The renewal of the Netherlands]. Locus Semin 4:11-16

Kovař́k P, Kutal M, Machar I (2014) Sheep and wolves: is the occurrence of large predators a limiting factor for sheep grazing in the Czech Carpathians? J Nat Conserv 22(5):479-486

Leader-Williams N, Adams WM, Smith RJ (2010) Trade-offs in conservation: deciding what to save. John Wiley \& Sons, Hoboken, p 371

Lescureux N, Linnell JDC, Mustafa S, Melovski D, Stojanov A, Ivanov G, Avukatov V, von Arx M, Breitenmoser U (2011) Fear of the unknown: general knowledge and perceptions of the Eurasian lynx Lynx lynx in western Macedonia. Oryx 45(04):600-607

Linnell JDC, Swenson JE, Andersen R (2000) Conservation of biodiversity in Scandinavian boreal forests: large carnivores as flagships, umbrellas, indicators, or keystones? Biodivers Conserv 9(7):857-868

Linnell JDC, Swenson JE, Andersen R (2001) Predators and people: conservation of large carnivores is possible at high human densities if management policy is favourable. Anim Conserv 4(4):345-349

Lüchtrath A, Schraml U (2015) The missing lynx — understanding hunters' opposition to large carnivores. Wildl Biol 21(2):110-119

Manfredo MJ, Teel TL, Bright AD (2003) Why are public values toward wildlife changing? Hum Dimens Wildl 8(4):287-306

Marino A, Braschi C, Ricci S, Salvatori V, Ciucci P (2016) Ex post and insurance-based compensation fail to increase tolerance for wolves in semi-agricultural landscapes of central Italy. Eur J Wildl Res 62(2):227-240

Marshall K, White R, Fischer A (2007) Conflicts between humans over wildlife management: on the diversity of stakeholder attitudes and implications for conflict management. Biodivers Conserv 16(11):3129-3146

Mech LD, Boitani L (IUCN SSC Wolf Specialist Group) (2010). Canis lupus. The IUCN Red List of Threatened Species 2010: e.T3746A10049204. http://dx.doi.org/10.2305/IUCN.UK.2010-4.RLTS. T3746A10049204.en

Natori Y, Chenoweth R (2008) Differences in rural landscape perceptions and preferences between farmers and naturalists. J Environ Psychol 28(3):250-267

Naughton-Treves L, Grossberg R, Treves A (2003) Paying for tolerance: rural citizens' attitudes toward wolf depredation and compensation. Conserv Biol 17(6):1500-1511

Nordström Källström H, Ljung M (2005) Social sustainability and collaborative learning. AMBIO 34(4):376-382 
Nowak S, Mysłajek RW (2016) Wolf recovery and population dynamics in Western Poland, 2001-2012. Mamm Res 61(2):83-98

Nyhus P, Fischer H, Madden F, Osofsky S (2003) Taking the bite out of wildlife damage the challenges of wildlife compensation schemes. Conserv Pract 4(2):37-43

Persson J, Rauset GR, Chapron G (2015) Paying for an endangered predator leads to population recovery. Conserv Lett 8(5):345-350

Pijpker J (2015) Wolf keert na ruim een eeuw terug in Nederland. http://www.nrc.nl/nieuws/2015/03/07/ wolf-keert-na-ruim-een-eeuw-terug-in-nederland Accessed 07 March 2015

Reimer AP, Thompson AW, Prokopy LS (2012) The multi-dimensional nature of environmental attitudes among farmers in Indiana: implications for conservation adoption. Agric Hum Values 29(1):29-40

Røskaft E, Bjerke T, Kaltenborn B, Linnell JDC, Andersen R (2003) Patterns of self-reported fear towards large carnivores among the Norwegian public. Evol Hum Behav 24(3):184-198

Røskaft E, Händel B, Bjerke T, Kaltenborn BP (2007) Human attitudes towards large carnivores in Norway. Wildl Biol 13(2):172-185

Sandström C, Johansson M, Sjölander-Lindqvist A (2015) The management of large carnivores in Sweden: challenges and opportunities. Wildl Biol 21(3):120-121

Sangay T, Vernes K (2008) Human-wildlife conflict in the Kingdom of Bhutan: patterns of livestock predation by large mammalian carnivores. Biol Conserv 141(5):1272-1282

Sjölander-Lindqvist A, Johansson M, Sandström C (2015) Individual and collective responses to large carnivore management: the roles of trust, representation, knowledge spheres, communication and leadership. Wildl Biol 21(3):175-185

Thorn M, Green M, Scott D, Marnewick K (2013) Characteristics and determinants of human-carnivore conflict in South African farmland. Biodivers Conserv 22(8):1715-1730

Treves A, Karanth KU (2003) Human-carnivore conflict and perspectives on carnivore management worldwide. Conserv Biol 17(6):1491-1499

Treves A, Naughton-Treves L, Shelley V (2013) Longitudinal analysis of attitudes toward wolves. Conserv Biol 27(2):315-323

Van den Born RJG (2006) Implicit philosophy: images of the people-nature relationship in the Dutch population. In: Van den Born RJG, Lenders HJR, De Groot WT (eds) Visions of nature a scientific exploration of people's implicit philosophies. Lit-Verlag, Berlin, pp 61-84

Van den Born RJG (2007) Thinking nature: everyday philosophy of nature in the Netherlands. Dissertation, Radboud University Nijmegen

Van den Born RJG (2008) Rethinking nature: public visions in the Netherlands. Environ Values 17(1):83-109

Vaske JJ, Jacobs MH, Sijtsma MT (2011) Wildlife value orientations and demographics in The Netherlands. Eur J Wildl Res 57(6):1179-1187

Verbrugge LNH, Van den Born RJG, Lenders HJR (2013) Exploring public perception of non-native species from a visions of nature perspective. Environ Manag 52(6):1562-1573

Verschuren P, Doorewaard H (2010) Designing a research project, 2nd edn. Eleven International Publishing, The Hague

Vitters $\varnothing$ J, Bjerke T, Kaltenborn BP (1999) Attitudes toward large carnivores among sheep farmers experiencing different degrees of depredation. Hum Dimens Wildl 4(1):20-35

Zweers W (2000) Participating with nature: outline for an ecologization of our world view. International Books, Utrecht 